\title{
Matt Morgan: When nothing is the right thing to say
}

\author{
Matt Morgan intensive care consultant \\ University Hospital of Wales
}

I slept dreadfully that night. I fought with my pillow and perched on the narrow corner ledge of my mattress, almost falling to the floor despite the adequate space next to me. The next day I found myself trying to cheat my circadian rhythm with a double espresso in my favourite cafe, contemplating a trip to the gym to short circuit my tiredness.

The previous night I had arrived home from work after midnight, when the children were dreaming, the dog was snoring, and even the lampposts had been extinguished. But my turmoil was completely insignificant when compared with that felt by the young girl I'd spoken to who had lost her mother an hour earlier after a cardiac arrest at the gym.

"I just want my mum back," she told me. There was little that could be said in response. I can still see the faded design on her $\mathrm{T}$ shirt and the creases on her face where her hands had been covering her eyes. I fumbled a response, telling the family about the psychological support we offer and handing over a leaflet into their shaking hands. "You are the bravest girl I have ever met," I said.

\section{Sitting in the rubble}

Medical school, postgraduate exams, and interviews all challenge us to solve difficult problems. Research gives us evidence to apply, algorithms to follow, and certainty to rely on. Yet the most difficult moments in medicine are those when there are no solutions. Our nature as healthcare experts is to fix, to solve, and to resolve. But some questions will simply hang over us, with no answer to hand or even ever possible.

I have thought a lot about that little girl and her family. I have thought a lot about what I should have said differently. Eventually, what helped the most was when I came across a phrase used by an amazing social worker, Liz Crowe, who has worked extensively for over 20 years with people affected by grief and loss.

Borrowing a phrase from Judith Murray's book Understanding Loss, Crowe said that sometimes our role should be to simply "sit in the rubble" with families. I now know that I should have said something different to that girl-I should have said nothing. I should have just sat in the rubble with her.

As someone who has been taught, mentored, and motivated to build answers out of rubble, sitting in it can be uncomfortable. But sometimes it is more important than making structures that will simply fall to the ground.

Competing interests: I have read and understood BMJ policy on declaration of interests and declare that I have no competing interests.

Provenance and peer review: Commissioned; not externally peer reviewed. Matt Morgan is an honorary senior research fellow at Cardiff University, consultant in intensive care medicine, research and development lead in critical care at University Hospital of Wales, and an editor of BMJ OnExamination.

Published by the BMJ Publishing Group Limited. For permission to use (where not already granted under a licence) please go to http://group.bmj.com/group/rights-licensing/ permissions 